NEW LITERARIA-

An International Journal of Interdisciplinary Studies in Humanities

Volume 2, No. 2, July- August, 2021, PP. 40-49

ISSN: 2582-7375

DOI: https://dx.doi.org/10.48189/nl.2021.v02i2.006

www.newliteraria.com

\title{
Pandemic as a Metaphor for Moral Degeneration in Tagore's Rajarshi
}

\section{Ananya Chatterjee}

\begin{abstract}
This paper shall unpack the Pandemic by reading the metaphor of moral degradation that gets regularly associated with disease and death. Tagore's novel contemplates this metaphorical association and undoes it by locating human agency outside of naturalized morality. The paper establishes Tagore's modernist understanding of human agency and responsibility through two characters - Gobindamanikya and Bilwan. The protagonist, Gobindamanikya, exemplifies Tagore's personal form of Virtue ethics, whereas in Bilwan we see a more practical equivalent of that Virtue ethics in the form of an ethics of care. A formidable opposition to their ethical positions is provided by the character of Raghupati, who invokes the natural order to establish a deontological view of reality. Within this naturalistic deontological worldview, calamities like the pandemic become almost an agreeable occurrence, thus testing the validity of both the positions of Bilwan and Gobindamanikya.

By looking at the thanatopolitics of the pandemic situation in the Indian subcontinent, this paper will analyse the assumptions about moral degeneration that cropped up during an epidemic in Tripura. The absence of a mature understanding of the human-nature relation results in conflicting moral stances on both the individual level and between two different religious communities. The paper will explain how the central characters stage a denaturalization of traditional authority through the moral intervention of the central characters. Tagore's novel establishes a mature vintage point from which humanitarian action can be conducted in the event of an epidemic or pandemic.
\end{abstract}

Keywords: Degeneration, Morality, Virtue Ethics, Pandemic, Sacrifice.

\section{Introduction}

Rabindranath Tagore's historical novel Rajarshi (1887), otherwise known as The Royal Sage, can be perceived in terms of a sequence of moral conflicts and ethical choices made by the multiple characters. The general trajectory of events in Rajarshi results from an interplay of the moral positions of the individual characters. The sequence of events and the conception of moral contamination in the world are initiated at the beginning with a single innocent question put to Gobindamanikya, the seventeenth-century king of Tripura, by a girl called Hashi: "why so much of blood" (Tagore, 1961). [Passages from the original novel have been translated into English by me.] Although Hashi asks the question in the particular context of the sacrifices taking place at the temples, to the protagonist's and the reader's ears the comment rings with the picture of the ubiquity of violence in the world. This pervasive presence of violence is most obvert when the plague appears and causes a climax that tests the moral compasses of the characters to their extremes. At the inception of this test lies Hashi's question which causes a gradual moral transformation in Gobindamanikya through the course of the novel. The immediate outcome of this ethical challenge is the banning of the sacrificial rituals by the king. The final point of this transformation is a self-sacrifice that makes Gobindamanikya the 
appropriate ruler of the kingdom, the rajarshi.

The relation between human moral fallibility and environmental degeneration is established in the novel since, following the alteration of the ritualistic practice, the kingdom experiences some degree of decline in its fortunes, mostly cost by a bad year in agriculture. A political drama is initiated owing to this action by the king since the royal priest, Raghupati's ego is hurt by the royal decree, which makes him plot against Gobindamanikya with the king's brother, Jaysingha and the Mughals. The decline of Tripura is only aggravated once Gobindamanikya abdicates and goes into exile, finally culminating in an epidemic affecting the people of Tripura. A conflict over the convention of animal sacrifice in Tripura becomes the core point of moral contention between the two sides. The spiritual content of the sacrificial ritual is held as fundamental to the constitution of the state by Raghupati. Gobindamanikya, on the other hand, considers it time for the state to outgrow the mechanical religiosity of rituals, and realize the true spiritual content that is expressed through human rational, artistic and moral agency. As I will show, Tagore bases Gobindamanikya's position on an understanding of the relation between the spiritual order and the body politic on the Upanishadic understanding of the act of sacrifice.

In Homo Sacer, Giorgio Agamben notes that the modern nation-state emerged through "the demystification of the sacrificial order" (Agamben, 2017). The modern political order thereby undid the opposition between the sacred and the profane as such. The modern citizen, divorced from any spiritual content, is hence a biopolitical subject, a bare life. The homo sacer has traditionally been the subject who has been rejected any spiritual content, rendered profane, unsacrificable but killable without any legal consequences. Exiled to the boundaries of the state and legality, they used to determine the natural limits of the state. But, following the dissolution of the profane and the sacred, the homo sacer is now not the exception but the normative political subjects. Agamben thus finds the nativity of the modern subject in the death of spirituality and the sacrificial order. It however needs to be taken into account that this modern transformation is specific to Western civilization since it is affected by the industrial revolution and the rise of capitalism. With Tagore, we witness a different dynamic of the spiritual order which, in its own way, develops modernity out of an indigenous culture of sacrifice. In the case of the historical change narrativized by Tagore, the modern subject born out of the end of sacrificial rituals is not less spiritual but more so in a truer sense. The difference between the two positions can be understood from the difference in understanding of sacrifices between Abrahamic and Upanishadic traditions. This, in turn, would enable an understanding of Tagore's alternate modernity and assist us in making our way out of a regressive moral perception of the present pandemic.

For the purpose of this paper, we further need to consider the relationship between the sacrificial rituals and the metaphor of contamination. Moral contamination renders the homo sacer unfit for the sacrificial ritual since his profanity would compromise the spiritual content. Raghupati immediately brings a moral angle to the troubles affecting Tripura the king of sacrilege. Gobindamanikya is thus branded as an equivalent of the homo sacer, the source of contamination, to be either killed or ousted. Later, those killed by the plague are given the same status of the homo sacer as they are denied funeral rites. The easy identification of moral degeneration with a pandemic situation thus displaces human concern and efforts. Hence, the novel notes the problematic nature of the metaphor of moral degeneration which prevents proper assessment and reactions to the situation. This moral displacement itself becomes the cause of the actual dilapidation.

Raghupati's and his allies's wounded egos cause a breakdown of the organic relation between the kingdom and its natural ruler, thus leading to the real decline. So, the downward curve in the novel is caused by offended human egos, and the kingdom is saved from this dark path by the sacrifice of the ego by Gobindamanikya. When Tagore adapted Gobindamanikya's story as a play, he titled it Bisharjan (1890) or Sacrifice. While both boli and bisarjan signify the act of sacrifice, the former denotes a more fetishistic form of sacrifice and the latter denotes 
a metaphorical idea of sacrifice. A more appropriate translation of the word bisarjan would be relinquishment or self-offering, thus denoting more of an attitude rather than an action. The play's title thus expresses a preference for Gobindamanikya's symbolic and curing selfsacrifice over the more orthodox sacrificial rituals. In fact, the latter practice is the actual affliction affecting society. Before discussing the significance of the epidemic episode of the novel, we need to take into account the underlying philosophy and cultural context of the sacrificial order. This would allow us an understanding of the operations of thanatopolitics in India in a manner that is culture-specific.

\section{Individual Morality and the Ethics of Sacrifice}

It must be noted that the novel does not provide a clear black and white opposition between the ideological positions of Gobindamanikya and Raghupati. Apart from their conflicting ideas of spirituality, the two characters represent two contradictory sociological worldviews, each with partial validity. Rather than playing the judge on their behalf, the novel, hence, provides the readers with an ethical dilemma that is particularly relevant in the time of the pandemic. In her chapter "Introduction to Ethics", Karen L. Rich defines ethics as a branch of philosophy that is used to study ideal human behaviour and ideal ways of being (Rich, 2005). Tagore makes his readers understand, analyse and distinguish right from wrong, and admirable from deplorable, as and when they relate to the larger-than-life characters. This process takes place on the individual level for the protagonist, who emerges as a yardstick of morality only at the end of the novel. Before that, he had to undergo a journey towards the balance of reason and emotion.

Tagore's unique blend of ethics in the case of Gobindamanikya, we note, is personbased and not action-based, just like the principles of Virtue ethics. Tagore makes the readers examine Gobindamanikya's virtues and the transformations in his moral character as he carries out the actions that make him both a king (raja) and a sage (rishi). According to BBC,

Virtue ethics not only deals with the rightness or wrongness of individual actions, it provides guidance as to the sort of characteristics and behaviours a good person will seek to achieve. (Virtue ethics, n.d.)

Thus, we find an indigenous flavour of Virtue ethics reflected in the character of Gobindamanikya. Iris Murdoch argues that "[i]n the moral life the enemy is the fat relentless ego" (Murdoch, 2013). Tagore, in Rajarshi, describes the killing of that ego in order to attain true peace in life and thereby the social order. The young priest Bilwan exemplifies the practical aspect of Gobindamanikya's internal Virtue ethics, since Bilwan works in the immediate proximity of victims of the epidemic. Gobindamanikya manifests the same morality in a different manner as he takes care of the children of the realm during his exile.

In spite of the antagonistic and deplorable role of Raghupati, he provides in the novel a moral point-of-view that merits serious consideration. In fact, to Hashi's question- "Why so much of blood" (Tagore, 1961, p. 5)- he provides the most efficient answer:

Listen, my disciple, as I deliver another lesson onto you. There are no such things as sin and virtue. What is your father to you? What is your mother to you? What is your brother to you? What is anyone to you? If all murders are sin then all murders are the same. But which authority proclaims murder sin? Deaths take place every day. Someone dies upon being hit on the head by a piece of rock, someone dies in a flood, someone dies by the plague, and someone else dies by the strike of a knife. Consider the many ants we kill everyday beneath our feet. How different are we from those ants? We are not above the play of life-and-death that affects these ants, not above the allpowerful Maya. Millions of such lives are sacrificed every day before that Fateembodying Mahamaya - from around the world, the blood of these beings trickle down to that bowl from which she drinks. Let us say I add another into that flow another drop of blood. Some day of the other, she would have taken that drop of blood for herself. Let me just provide the occasion for that. (Tagore, 1961)

The target of this diatribe is not Hashi, but Jaysinha, whom he wants to incite so as to overhaul 
the existing regent and establish his own puppet on the throne. Raghupati emphasises the fulfilment of duties or rules when he influences Jaysinha to kill the king. His approach is deontological, especially when he incites Jaysinha by saying that there is nothing called sin or piety- the entire world is a system where time is doing its own work irrespective of the actions of mere humans. He asks Jaysinha to assassinate the king as a duty towards God. He resents the king's decision about the stopping of animal sacrifices, and thus uses Jaysinha as a tool in order to satisfy his own ego.

The most effective part of the deontological argument of justified violence delivered by Raghupati is its grounding in the general course and will of nature. The equation of human lives with ants establishes the arbitrariness of the humanitarian will which gets motivated on only certain occasions and can act casually on other occasions. In the condition of a pandemic, this worldview would actually advocate non-intervention and passivity in the face of danger for others and for oneself. To a modern reader, the seriously inhuman and indeed psychopathic implications of Raghupati's rivals the grave pathological implications of a pandemic such as Covid-19.

The nihilistic indifference preached by Raghupati to his disciples might remind us of the detachment taught by Krishna to Arjuna in the Shrimad Bhagavad Gita. But, this rendition of Hindu philosophy is not attained by Raghupati without some degrees of manipulation and departures. While the realization of the ubiquity of violence in the world features in the Upanishad, the text also makes a crucial distinction between Vedic sacrifices and asuric sacrifices (Das and Nandi, 1985). Besides the mode of killing as prescribed in the scriptures, the two forms of sacrifice differ essentially in terms of the relation between the sacrificiant and the victim. In case of the asuric sacrifices, the victim is a foreign object with no personal ties to the sacrificiant. On the other hand, in the case of Vedic sacrifice, the sacrifice of the victim must represent the symbolic relinquishment of something important by the sacrificient, and therefore a personal connection is essential between the victim and the sacrificient. In other words, the symbolic aspect of bisharjan is integral to the Vedic mode of boli. In out-ruling all categories of "sin and virtue" (Tagore, 1961), all forms of human relations and responsibilities, Raghupati ends up departing from the core value of Vedic sacrifice, and, in fact, renders religion devoid of all spirituality. The possible parallel with Bhagavat Gita actually serves to make this departure evident in his case. The problematic interpretation of this part of the Mahabharata later concerned Tagore, in greater detail, in the novel Char Adhay (Quartet) (1934). Indranath, the political revolutionary identifies with Krishna as he uses his followers as sacrificial pieces to further the cause of the freedom struggle. Just like Raghupati, Indranath comes to realize the folly of this literal reading and appropriation of the Gita towards the end of the novel, since he finally understands that this has only taken him away from his humanity and the original cause.

As opposed to Raghupati, Gobindamanikya appears to really depart from tradition but actually possesses a deeper understanding of the spiritual content of the Vedic rituals. What Tagore realizes through Gobindamanikya is that it is possible to retain the spiritual core of bisharjan without committing the violent act of sacrifice. Consequently, Gobindamanikya at once departs from and moves closer to the Vedic and Upanishadic notion of sacrifice. In relinquishing his kingdom, Gobindamanikya relinquishes the ego that engages in personal relations, but he does not relinquish those relations themselves. The dismissal of the value of human relations and emotions would, in the first place, render the act of sacrifice itself utterly meaningless. Jaysingha, who is, for the most part, a reluctant associate in Raghupati's ploy, realizes this annulling of individual subjectivity that effectively turns the sacrificial order, that is existence, meaningless and ultimately profane:

Is this why everyone calls you Mother, Mother? You are so lapidary! Monstrous as you are, you stick out that red tongue of yours to draw out and drink up the blood from all of existence! Affection, love, motherliness, beauty, dharma -everything is false! True is only this endless course of bloodlust! To satisfy your stomach will one man stab 
another's neck, brother will kill brother, father and son will hack at each other! Oh heartless! If this is the truth then why do not the clouds rain blood? Why the ever-pitiful river does not flow blood, and drop into an ocean of blood? No, no, no, mother! You tell me directly that this lesson is wrong, that this philosophy is wrong. That my mother should not be called mother but be called a bloodthirsty she-monster - I cannot bear such a knowledge. (Tagore, 1961)

Jaysingha's diatribe clearly displays that, in making the sacrificial order absolute, Raghupati has actually robbed existence of all spiritual content. The disappearance of all familial relations and human bonds not only dehumanizes human beings, but in turn renders the goddess herself void of divinity. She becomes a stone without any spiritual value or subjectivity. Quite contrary to Raghupati's worldview, the idea of Vedic sacrifice is impossible if there is nothing to be sacrificed but for material reality in the first place. In fact, according to Ramachandra Gandhi, the particular to the Hindu understanding of religious sacrifice is the subjectivity of the victim, which is a notion does not present in the Abrahamic take on sacrifices (Gandhi 1984). Gandhi elaborates this idea through a comparative reading of the Biblical story of Isaac and the parable of Naciketa from Katha Upanishad. In Isaac's case, Abraham agrees to sacrifice his son as per God's ordain, and Isaac himself has no say in the matter. Naciketa, on the other hand, recommends himself as sacrificial victim to his father, Vājashravas, who shall conduct the ritual. The son's reasoning is that the personal bond between the father and the son makes him sacrifice truly relevant. Raghupati's approach to death would render Naciketa's sacrifice meaningless, and therefore annulling the most vital aspect of the spiritual content.

It might be argued that Gandhi's out-ruling of any subjective Abrahamic victim is somewhat reductive of the Western tradition. Especially George Bataille's reflections on sacrifices and internal experience stand to disprove this reading. But a detailed analysis of this issue would be outside of the scope of the present paper. More relevant for our reflections on an Indian thanatopolitics would be Agamben's recognition of the unique take on the sacrificial order in the Vedas. Agamben understands via Marcel Mauss that in Rig Veda sacrifice is a mode of nourishment (in more than material sense) for both the humans and the gods (Agamben, 2017). The gods both nourish and are nourished through the sacrificial act in a manner reminiscent of Christ, who shared his flesh and blood. However, the effect of Hindu sacrifices is not just "influencing the gods; it creates them" (Agamben, 2017). Hence, in Agamben's reading, sacrifices according to the scriptures do not bring just death but also the birth of the gods themselves. This originary capability bestowed in sacrificial rituals makes them central to the world order in a quite different manner than generally understood. Raghupati's denial of the victim's subjectivity not only renders the entire order profane, but it also obstructs the very existence of the gods he worships. His deontological philosophy turns the Goddess into a stone. On the other hand, Gobindamanikya follows the path of ahimsa. In Tagore's version of his story, even his abdication and reinstation to the throne occur bloodlessly. Even while not partaking in any sacrificial act as such, Gobindamanikya realizes the creative aspect of self-sacrifice, when he gives up his ego, to be reborn. The presence of divinity in the human is realized by Tagore through such a rereading of Vedic philosophy.

\section{Morality, Ethics, and the Epidemic}

Invariable of his philosophical error, one has to appreciate the realistic detail in Raghupati's account of the world. Especially in the colonial era, during which Bengal would experience the Spanish flu as well as multiple cholera plagues, the ubiquity of violence noted by Raghupati rings true for the world around. In Raghupati's worldview, violence is the most integral element of the natural course of events, as it is designed by the divine will. Within this paradoxically chaotically systematic scheme of life, the tender emotions of the human heart are indeed the factors that are out of place. This would mean that human intervention is the most unwanted factor for the divine forces running the world. The thanatopolitical ubiquity of blood and death 
on the earth would render every human being into a homo sacer at whose death we should neither be shocked nor excited (Agamben, 2017). This would also render the many lives lost under the ruthless machine of a calamity an eventuality not worth our intervention.

The point that Tagore is making in the novel is that even if what Raghupati is saying is the unmistakable truth, that does not make it acceptable. Hence, the moral determinism that accuses victims of some form of degeneration or the other is actually a sign of irresponsibility, since it advocates the disregard for actual causes and disavowal of all humanitarian actions. The continuity between the human and nature that is exemplified by Tagore's narrative does not eliminate this extra-natural understanding of morality in the novel. Rather, Rajarshi occupies a central position within the natural order because his Virtue ethics both encapsulates and transcends the will of nature, or of the conventional divinity. He embodies the Upanishadic divinity precisely because Gobindamanikya's Virtue ethics allows him to give a new direction to the natural world around him. This synchronism with the natural order is made evident at the moment when, during his meditative presence in nature, despite being unguarded, he emits an invincible aura. On the other hand, Raghupati appears more impressive in terms of a practical understanding of life. Natural validity and invalidity are beside the point here. More importantly, a moral degeneration occurs when one's moral outlook beings nothing new or authentically individualistic to the overall scheme of things.

On the other hand, Gobindamanikya's own ethical position is not a pregiven ideal position. The novel portrays him as continually outgrowing his present moral disposition in order to attain a more refined understanding of Virtue ethics. The most important factor becomes his process of transformation from a king to a sage:

Relinquishing one's kingdom all of a sudden would seem easier in writing, in life, however, it was a much trickier affair. Wearing saffron after abandoning the king's robes was not a small sacrifice. Perhaps letting go of one's kingdom was easier, but we cannot possibly abandon our tiny, lifelong habits with ease, since they merge with our bones and flow through our bloodstream bearing an insatiable hunger; if we try to starve them, they keep sucking the blood out of us (Tagore, 1961).

Tagore states that the reader should not assume that while Gobindamanikya was staying alone in his cottage, and that he was sitting still in a state of calmness. In actuality, he had constantly been fighting against his thousand, tiny, lifelong habits. The act of bisharjan or self-sacrifice might be heavily contemplative. But, a heavily active act, to be realized through everyday practice as well as psychological conviction. Whenever the lack of luxury made his heart wrench in desire, he started chastising and reproaching himself severely. "He was constantly trying to kill his thousand-faced hunger by ruthlessly starving them" (Tagore, 1961). He found fulfilment by gaining a victory over his desires in every step.

The exiled Gobindamanikya realizes his humanitarian destiny while living among a group of orphaned children whose lives are given a new direction by him. He further motivates Bilwan, a priest who reciprocates his progressive viewpoints. Through Bilwan, we see the most relatable practical orientation of the moral axis in Rajarshi that would resonate with a postCovid-19 reader.

While dealing with the pandemic situation among the Muslim and the Hindu communities, there are hostilities among the masses. However, the Hindu priest, Bilwan, does not discriminate according to caste, but helps the people with equal zeal for service. This epidemic, depicted at a crucial moment after Gobindamanikya had left the kingdom, indicates the lack of morality and virtue among the people henceforth. The forty-first chapter deals with a detailed description of the pandemic situation at Nijamatpur and its cause-flood. The epidemic could still have been avoided, but for the fact that the bodies of those dead from the flood are not given their last rites by the survivors, who were mostly strangers to the dead, whose bodies have flown in from other villages. These neglected bodies, thus rendered into homo sacer, rot while neglected, leading to the infectious disease. Hence, the epidemic becomes a testament to a moral failing, not because it is god-given, but since it originated out 
of human negligence.

Religion-based discrimination has an intrinsic connection with the entire epidemic situation. Just like the ideological conflict between Gobindamanikya and Raghupati, in this case a conflict, originated between two religious communities. The Pathans who were relatively unaffected by the flood contracted the disease first. A conflicting nature of the Abrahamic and the Hindu funeral rites meant that neither community could take care of their dead or their living. Tagore conveys that the moral determinism that keeps the two communities apart installs a false sense of spiritual purity. In fact, this insularity that disregards the essential human bond itself is the contaminative force that profanes lives. The politicization of the individual bodies in this manner, in turn, makes the body politic a contaminated and sacrilege entity.

Although centred around the regal figure of Gobindamanikya, the novel moves towards a democratization of Virtue ethics. Gobindamanikya has in the first place motivated Bilwan to move out of the capital and seek out opportunities to help the common men of the state, living in more obscure regions. This has brought him to Nijamatpur. Bilwan provides a moral and humanitarian sanctuary to the people there who are affected by the plague. As opposed to the religious orthodoxy of both the communities, Bilwan professes a spiritual humanism that seems to restore spiritual dignity to the human body. It must be understood that the word 'spiritual' is not meant in a restricted sense in this case. Rather, the spiritual content is the ethical basis on which everyday human dignity is established and practical operations are motivated. Bilwan's ethics of care manifest through practical actions, like the distribution of reliefs and medicines to the people of all communities. Such a comprehensive and democratic definition of humanity is observed by Tagore in the words rishi and sanyashi, as Bilwan explains: "I am a priest. I belong to no community. My community is humanity. When human beings are dying, what does community matter". (Tagore, 1961)

Bilwan's position stands for the modernist humanism practised by Tagore, who would himself, later on, go around and administrate medicine to people during the Spanish flu. Further, it must be noted how the logic of self-sacrifice as identified before is present within this speech. Bilwan has in effect sacrificed his communal identity. However, that sacrifice has not turned him inhuman. Rather, the creative effect of this sacrifice has been the realization of a new identity - the essential humanity of the individual. Further on, he is continually committing potential bisharjan by exposing himself to the epidemic in this manner. This sacrifice of self-interest that the people of Nijamatpur could not commit brought calamity to them. Bilwan's relinquishment of self-interest involves further the abstinence from any moral judgement of others. So, he puts both communal identity and moral judgement on hold in order to practice an ethics of care that is exemplary for any pandemic situation.

Very importantly, his ethics of care motivates other individuals, a group of youths, who engage in relief activities following his example. Thus, the occasion of the epidemic serves to organize a community of people who operate with a more constructive understanding of Virtue ethics. In the beginning, the Hindus could not decide whether Bilwan's actions were good or not. Their incomplete knowledge of the scriptures said that the actions which did not mind religious divisions were not good. But, the more innate presence of human conscience residing within their heart resulted in the creation of a Virtue ethics that looked beyond such divides. When the pandemic attacked the Hindus, the Muslims started looting their homes. Bilwan prevented them as far as possible, thereby maintaining peace in Nijamatpur. Slowly, the people came to understand Bilwan's position, they dropped their suspicions regarding his role in the communities and came to appreciate and assist him.

\section{The Pandemic and Tagore's Metaphorical Imagination}

This is the process through which Tagore makes a case for the Virtue ethics of the postRomantic democratic order. Especially today, when a large number of religious communities tend to consider the Covid-19 pandemic as a metaphor of moral degeneration and its 
punishment, this post-romantic Virtue ethics teaches us to not seek out every reason within a presumed natural moral order. The sense of entitlement and exclusivism that certain community members harbour against the sway of the disease is often grounded upon this construed understanding of natural morality, one that Raghupati for instance exemplifies. But, Bilwan's ethics of care and Gobindamanikya's progressive politics makes us understand that the directions taken by history are not necessarily always about natural causation. Rather, certain people attribute natural causation to otherwise arbitrary or abnormal events (like this pandemic) to substantiate their own ideological positions, however absurd the reasoning might resultantly become.

This prejudicial understanding of the pandemic is not a simple factor that should be dismissed without much thought. As Adrian J. Ivakhiv notes, such behavioural patterns give us vital anthropological insights into the way pandemics are understood and experienced by humans. The positing of some moral reason behind the occurrence of some natural calamity or disease is in no way a new phenomenon. The supposition of some natural and moral cause behind any arbitrary occurrence is indeed the best way of resolving the epistemological challenge encountered on such events. We need to delve into the epistemology of the pandemic to understand how thanatopolitical understanding and the ethics of care spoken about in this paper make a difference on such occasions.

Ivakhiv notes that the instinctual suppositions of exclusivism and moral immunity kick in on such occasions since people in general, are extremely frightened during any pandemic situation. The situation is not alleviated even by the proliferation of information and scientific knowledge in the contemporary world.The problem with the pandemic is that it calls on so many types of depth expertise, the kind that contemporary science excels at with its hyperspecialization, yet the interdisciplinary expertise- what we might call lateral expertise- of bringing them all together is in short supply. "This is the epistemological crisis of the moment," says media sociologist Zeynep Tüfekçi: "There's a lot of expertise around, but fewer tools than ever to distinguish it from everything else." The pandemic, Yong argues, "exploits our cognitive biases." "We crave simple narratives, but the pandemic offers none." (Ivakhiv, April 20, 2020)

In Tagore's vocabulary, this craving for a narrative that addresses the epistemological crisis is essentially the spiritual crisis that occurs with the profanation of religion. The drive for narratives can result in moral exclusivism if in the first place the individual has not relinquished self-interest. The humanitarian mind that Tagore sees as pertinent for modernity is not a secular imagination nor a strictly religious mentality, but a metaphorical imagination that retains the spiritual within the secular order. The interdisciplinary expertise that Ivakhiv seeks may be considered as realizable with such a philosophical framework, not because this metaphorical imagination would allow a mastery of all disciplines and arts. But, because such an approach acknowledges the depth and relative validity of all disciplines. (A discussion of Tagore's pedagogic model underlying the institution of Shantiniketan would be interesting from this angle, but it would be beside the concern of the current paper.)

Tagore's modernism has to be classified as post-Romantic since he realizes that the easiest and most convenient of narratives are supposedly offered by nature, and therefore the human mind first and foremost looks for a natural cause for everything. This reliance upon nature also makes human beings heavily exploitable. Thus, Raghupati achieves his political goals by manipulating the opinion of the general populace by citing natural causes, as already seen. On the other hand, Gobindamanikya and Bilwan's moral stances are post-romantic, not because they are both defying natures. On the contrary, they have a more intimate understanding of nature, and of the fact that the relations of causation cannot be so conveniently attributed to nature, which itself is much more dynamic and protean. The knowledge of the sacrificial order shows the mutually nurturing relationship between the human, nature and divinity, a relation in which no one is absolutely at the mercy of anyone. So, there is no essentialization and prediction of the courses of nature possible. This means that they draw 
their moral strength not from just nature or divinity, but from inner conviction, even when that conviction and conscience run against the courses of conventional knowledge. So, Gobindamanikya exists according to a correspondence between nature and the human being. This correspondence further becomes the authentic base for a democratic body politic.

\section{Conclusion}

The practice of using pathological disorders as manifestations of moral and societal degeneration is quite common in literature, whether in India or in Western literature. Tagore's Rajarshi as well opts for the same metaphor. However, it carries the metaphor well beyond its conventional limitations, and shows how the populace is responsible for either aggravating or alleviating the situation. So, the metaphor of the pandemic becomes more than a trope in his hands. It serves as a situation that establishes the possibility of a democratic dealing with human problems.

According to Antonia Peacocke as well, beyond the metaphor of pandemic lies the communal and constitutive power of metaphors, which become more evident in such times of crisis. He notes:

Metaphors are some of the greatest tools of human expression. They let us expose rich textures of commonality between things. They let us in on fine shades and details that we might have otherwise missed in a situation. They can be remarkably forceful, they can stick around, they can have great emotional power, and they can bring us together in the way we see and conceptualize the world. (Peacocke, 2020)

As noted, Virtue ethics denotes the internal disposition of a character, but it does not necessarily determine the a priori content of the individual. It perhaps is more convenient to think of Virtue ethics in terms of metaphors, so as to have a more flexible understanding of normative ethics. In that case, metaphors have the ability to establish a Virtue ethics on a more communal scale, as visible in Tagore's novel. The metaphorical flexibility of virtues gives them a dialectical character, which better explains how the internal virtues can interact and influence the outer reality. This dialectical connection between the self and the society explains how individuals, whether royal or not, effectively demonstrate an ethics of care during a pandemic situation.

\section{References}

Agamben, G. (2017). The Omnibus Homo Sacer. (Heller-Roazen, Daniel, Trans.). Stanford University Press.

Chappell, T. (2014). Knowing What To Do: Imagination, Virtue, and Platonism in Ethics. Oxford University Press.

Das, V., \& Nandy, A. (1985). Violence, Victimhood, and the Language of

Silence. Contributions to Indian Sociology, 19(1), 177-

195. https://doi.org/10.1177/006996685019001011

Gandhi, R. (1984). I am Thou. Poona: Philosophical Quaterly.

Ivakhiv, A.J. (April 20, 2020). Pandemic epistemology. Immanence. https://blog.uvm.edu/aivakhiv/2020/04/30/pandemic-epistemology/

Murdoch, I. (2013). The Sovereignty of Good. Routledge.

Peacocke, A. (July 20, 2020). The Value of Metaphor in a Pandemic. Philosophy Talk. https://www.philosophytalk.org/blog/value-metaphor-pandemic

Rich, K. L. (2005). "Introduction to Ethics". In J.B. Butts and K.L. Rich (Eds.) Nursing Ethics: Across the Curriculum and Into Practice (pp. 1-23). Sudbury, MA: Jones and Bartlett.

Shale, S. (July 17, 2020). Moral injury and the COVID-19 pandemic: reframing what it is, who it affects and how care leaders can manage it. BJM Leader. https://bmjleader.bmj.com/content/4/4/224 
Tagore, R. (1961). Rajarshi. Visva-bharati Library.

Virtue ethics. (n.d.). BBC. https://www.bbc.co.uk/ethics/introduction/virtue.shtml

\section{$\underline{\text { Bio-note }}$}

Ananya Chatterjee is an Assistant Professor in English at Balurghat College. She had formerly been an Assistant Professor at JIS College of Engineering, Kalyani. She is currently pursuing her $\mathrm{PhD}$ at Techno India University, Kolkata. She completed her graduation and master's degree in English from the University of Calcutta. She has contributed research articles to several books and academic journals. Her specialization includes Tagore Studies and Gender Studies. She is also a published poet and short story writer.

Email Id: ananyachatterjee.bubu@g 